\title{
Simon Tünde
}

PhD-hallgató, Szegedi Tudományegyetem Neveléstudományi Doktori Iskola

\section{A vizuális kommunikáció képességcsoportjának értelmezése és fejlődése 10-12 éves korban}

A 20. században a verbalitással szemben elótérbe kerüló vizuális befogadás, megismerés és kommunikáció egyre összetettebb hétköznapi elemei közötti eligazodás igénye irányitotta a figyelmet a vizuális nevelésre, a képi gondolkodás és elemzés megismerésére, a vizuális nyelvre és az alkotó képzelet fejlesztésére (Feuer, 2000;

Bodóczky, 2009; Horányi, 2003; Kárpáti és Gaul, 2011). A vizuális kommunikáció folyamatosan és dinamikusan fejlódó diszciplina, kutatását tágas megközelitések, változó tartalmak jellemzik (Róka, 2002; Elkins, 2003; Jensen, 2003; Duchowski, 2007). Tudománnyá érése ma is folyik, kutatásának relevanciáját támasztja alá, hogy egyre nagyobb részt követel a közoktatásban és az egyetemi rendszerekben (Antik, 2010). Kepes (1979) szerint a vizuális nyelv minden más kommunikációs eszköznél hatékonyabban képes a tudást terjeszteni. A vizuális kultúra elemeinek integrációja mindennapjainkba a digitalizációval radikálissá vált. A technológiai fejlódés nem csak mindennapi életünket befolyásolja, hanem az oktatás, a mérés-értékelés folyamatára is jelentôs hatást gyakorol (Mitra, 2013; Brown, 2005; Csapó, Molnár és R. Tóth, 2008).

A tanulmány célja a vizuális kommunikáció tudományának, oktatási lehetóségeinek és képességcsoportjának leirása a hazai

és nemzetközi szakirodalom alapján, mely szakirodalom alapja a további kutatásoknak és pedagógiai javaslatok kidolgozásának a mindennapi vizuális kommunikáció hatékonyabb oktatásához.

\footnotetext{
A személyiség több rétegét megmozgató, értelmi és érzelmi folyamatokat, akaratlagos és önkéntelen reakciókat mozgásban tartó müvészeti nevelés a 20. században egyre több kutatás tárgyává vált. A vizuális nevelés fogalma összefonódott az önkifejezéssel, az élményképzéssel és a kommunikációval. A harmincas években a müvészettörténet és a lélektan elemezni kezdte a gyermekrajzokat, megjelentek az elsö, gyermekrajz fejlődését leíró tanulmányok (Paál, 1970; Mendelowitz, 1953; Kellogg, 1969). A hatvanas években a világ számos pontján megkezdődött a rajzkészség standardizált értékelése, melyhez a magyar kutatók is csatlakoztak (Gerö, 1973; Feuer, 2000; Kárpáti, 2001; Kárpáti és Gaul, 2011). Ezzel párhuzamosan elindultak a kutatások a
} 
gyermekrajzok tartalmának pszichológiai, esztétikai minőségének mérései, diagnosztikus, terápiás alkalmazási lehetőségei témaköreiben (Feuer, 2000; Vass, 2006).

A vizuális kultúra elemeinek mindennapjaink részévé válása a digitalizációval radikálissá vált, az esztétikailag meghódított valóság vívmányai folyamatosan áramlanak a mindennapi életbe (Achen, 1981; Arnheim, 2004; Nyiri, 2000a, 2000b, 2002, 2008). A rendkívül gyorsan változó, szimbólumokban gazdag gépi-képi kultúra a társadalom széles rétegét érinti. A technológiai fejlődés egyúttal kitágította az eddig is rendkívül összetett vizuális produktum fogalomkörét, új képnyelvi lehetőségek tárultak fel, ezért egyre nagyobb feladatot jelent ezt a heterogén, szinte végtelen megjelenési formájú világot úgy leképezni, hogy a befogadó számára értelmezhető legyen (Töreky, 2002). A klasszikus és kortárs médiumok sokféle nyelvezete áll rendelkezésünkre. Számos tanulmány foglalkozik a vizuális kommunikáció értelmezésével, a látás nyelvével, és az ezzel párhuzamosan kialakult új tudományággal, a vizuális szemiotikával (Horányi, 1975, 2003a, 2003b, 2006; Kepes, 1979; Miklós, 1980; Peternák, 1992, 1993; Kárpáti, 1991, 2001, 2005). A vizuális kommunikációról sokféleképpen lehet gondolkodni, értelmezését nem lehet elválasztani a kommunikációkutatásban elért eredményektől, a vizuális percepció fogalmától, illetve a társadalmi viszonyokban betöltött szerepétől. A vizualitás kommunikációs világa összekapcsolódik a szociális meghatározottságában élő ember általános, gyakorlati kommunikációs elvárásaival és lehetőségeivel. A vizuális képességek vizsgálata, a mérési eredmények és a tudományos háttér támpontot biztosít ahhoz, hogy képesek legyünk alkalmazkodni a változásokhoz. A kép, a képi ábrázolás, a képek kapcsolatteremtő, információközvetítő, kultúraarchiváló szerepének fogalomköre, a legkülönfélébb módon készült vizuális alkotások vizsgálata hozzátartozik a vizuális kommunikáció értelmezéséhez.

A vizuális kommunikáció képességcsoportjának meghatározásához és leírásához elengedhetetlen a kapcsolódó fogalmak tisztázása. Ebben a tanulmányban a megkülönböztetést segítő és rendszerező áttekintést kívánok adni a vizuális kommunikáció értelmezéséhez, valamint felvázolom a vizuális kultúrának és a vizuális kommunikációnak közoktatásban elfoglalt helyét, hagyományait és tantervi adottságait, értékelési lehetőségeit, bemutatva a vizuális gondolkodás fejlődéslélektani aspektusait.

\section{A vizuális kommunikáció a kommunikációelméletekben és a vizuális nevelés történetében}

\section{A vizuális kommunikáció a kommunikációelméletekben}

A látás nem csupán tárgyi jelenség, hanem az emberi világban való tájékozódás is egyben, a környezettel való szakadatlan interakciónak és kommunikációnak a lehetősége. A vizuális megismerés és megjelenítés eszköztára egy olyan nemzetközi és művészeti korokon átívelő egyetemes nyelv, mely elkerülhetetlen a világ megismeréséhez, a világban való tájékozódáshoz. Az ember alkotta, látható képek kommunikatív szerepeinek vizsgálata, a vizuális kommunikációról való gondolkodás jelenleg is erőteljesen formálódó diszciplína. A müvészet történetében a 20. századtól új vizuális nyelv alakul ki, melynek nyomán a képi jelek megszabadulnak tárgyi kötöttségeiktől, a vizuális nyelv önálló nyelvvé érik (Király, 1992; Baudrillard, 1987; Kince, 1982; Mirzoeff, 1999). Új vizuális energiák szabadultak fel. A pop art és a Fluxus mozgalom végletekig tágította a hagyományos művészeti eszköztárat, az eseménymüvészetek megjelenésével a mozgás, a vizuális esemény a valóság megismerésének eszközévé válik. Stílusok és témák zavarba ejtő és gazdag világát alakították ki a vizuális kifejezésnek, illetve új értelmet adtak a hagyományos képi kifejező eszközöknek (Ruhrberg, Schneckenburger, Fricke 
és Honnef, 2005; Bätschmann, 1998). Majd száz éve alkotta meg Otto Neurath (1980) a Tipografikus képi nevelés nemzetközi rendszerét (International System Of Typographic Picture Education, ISOTYPE), ezzel önálló vizuális logika mentén építette fel máig használatban lévő jeleit. Az ő munkássága mérföldkövet jelent a vizuális kommunikációban, nyomdokain indult el Arnheim (2004a, 2004b), aki a vizuális gondolkodás alapjait vizsgálta és fektette le.

A vizuális kultúra és kommunikáció kutatására dinamizmus és tágas megközelítések jellemzőek. A kialakuló diszciplína több tudományág 20. századi eredményeit is magába olvasztja: ide tartozik az etológia (Csányi, 1996, 2006, 2013), pszichológia, kulturális antropológia (Kunt, 2003), esztétika (Peternák, 1992, 1993), filozófia, jelelmélet (Neumann, 1989; Eco, 1998), kommunikációelmélet (Róka, 2002; Miklós, 1995; Antik, 2010), befogadáselmélet (Arnheim, 2004; Duchowski, 2007), valamint a szociológia és pedagógia (Kárpáti, 1995a, 1995b; Bakos, Bálványos, Preisinger és Sándor, 2000; Zombori, 1995; Szalontai, 1994; Bodóczki, 2002a, 2002b). A vizuális kommunikáció fogalmi megjelenése korábbi a vizuális kultúra fogalmánál (Elkins, 2003), Ivins (2001) a fogalmat könyvének címében is szerepelteti 1953-ban. A vizuális kommunikáció maghatározása a kommunikációtudományi szakkönyvekben nem egyértelmű formában és tartalommal jelenik meg. A témával foglalkozó tanulmányok többségében a verbális és nonverbális kommunikáció felosztás szerepel, mely utóbbit testbeszédként kezelik, a nonverbális kódok között sorolva a testmozgást, a szem- és az arcmozgásokat és az érintést (Infante, Rancer és Womack, 1991). A vizuális kommunikációt általában olyan kommunikációként határozza meg a szakirodalom, amelyben az üzeneteket képek továbbítják. A kép meghatározására is több variáció létezik a szakirodalomban. Searle (2003) a szobrokat is képként kezeli, Gombrich (1999) kizárólag a síkon megjelenő alkotásokat tekinti képnek, míg Miklós Pál (1980, 1995) a hétköznapi használati tárgyakat emeli be a vizuális kommunikáció rendszerébe. Ma a használati tárgyaink mindegyike egy vagy több struktúra tagja, és a funkcionális strukturáltságból eltolódnak a másodlagos jelentés felé, átkerülnek egy kulturális rendszerbe, mely rendszerben az információ, a tárgyi üzenetek folytonos áramlása hangsúlyos szerepet kap (Baudrillard, 1987). A design fontos kommunikációs elem, mely egyrészt a társadalmi-gazdasági jelzéseket juttatja a termékbe, másrészt a termék jelzéseit közvetíti a fogyasztókhoz. Erre a kétirányú kommunikációra épül napjainkban a reklámipar, mely fontos terepe a vizuális kommunikációnak. A tevékenység és a közlés oldaláról közelítve „a vizuális kommunikáció olyan közlést jelent, amely eszközeit és jelrendszereit a látható világból veszi, illetve amely a vizuális tevékenységben nyilvánul meg" (Zombori, 1995, 128. o.). Kepes (1965) szerint minden olyan ember alkotta és kommunikációs szituációban megjelenő üzenetfajtát, amit a szemünkkel érzékelünk, vizuális üzenetnek tekinthetünk, a képi gondolkodás pedig a külvilágból érkező jeleket strukturálja, alakítja értelmes dolgokká.

Jensen $(2003,208$. o.) úgy látja, hogy a vizuális kommunikáció kutatásában ,a továbblépés útja nem a nyelvi modell segítő támogatásával, vagy a lehetséges jelek peirce-i formális taxonómiáján keresztül vezet. Inkább interdiszciplináris elméletépítésre van sürgető igény..." A digitalizáció is ezt az igényt támasztja alá, amennyiben a nyelvi és a képi kommunikációnkról való gondolkodás új alapokra helyeződik a gépi-képi kultúra elterjedésével. A hypertext és az internet gyakran összemossa a két kommunikációs formát; kétségessé válik, hogy alkalmasak-e a korábbi fogalmaink a szöveg és a kép jellemzőinek leírására (Harnad, 2001).

A vizuális nyelv a látás nyelve, kódja ikonikus. Olykor másodlagos nyelvként is említi a szakirodalom, annak ellenére, hogy a vizuális nyelv nem ráépül a verbális nyelvre, hiszen a megismerési folyamatban, tevékenységben egyenrangú tényezőként szerepel szöveg és kép: 
„A vizuális nyelv minden más kommunikációs eszköznél hatékonyabban képes a tudást terjeszteni. Segítségével az ember tárgyi formában fejezheti ki és adhatja tovább tapasztalatait. A vizuális kommunikáció egyetemes és nemzetközi: nem ismeri a nyelv, a szókincs vagy a nyelvtan korlátait; egyaránt megérthetik írástudatlanok és müvelt emberek. Tényeket és eszméket nagyobb mértékben és mélyebbre hatolva tud közvetíteni a vizuális nyelv, mint más kommunikációs eszközök. A statikusan verbális fogalmat a dinamikus képnyelv érzéki elevenséggel képes életre gerjeszteni. Egy adott vizuális kép befogadása egyúttal azt is jelenti, hogy a szemlélő szintetizálási folyamatban vesz részt. Az érzékelt kép tapasztalása egyúttal alkotó integrációs tevékenység. Lényeges ismérve, hogy az alakítóképesség szerves egésszé formálja a tapasztalatot. Ez a formaadás alapiskolája, ami viszont formátlan világunk zürzavarában strukturális szempontból óriási jelentőségü." (Kepes, 1979, 6. o.)

A nem verbális és a vizuális kommunikáció kódjai történeti fejlődés eredményei és kultúraspecifikusak, a képi közlés a verbálishoz hasonló rendszerismeretet és tapasztalatot igényel. A vizuális nyelvi hatásokat befolyásolják az ember biológiai, pszichológiai feltételei, nézőpontja, társadalmi és kulturális meghatározottsága, a kép anyaga és a látvány komponált vagy nem komponált jellege (Rusbult, 1995). A vizuális nyelvi elemek egységei közé a vizuális dinamika, a hangsúlyozás, a szerkezet, a figyelemirányítás és az ezekhez szorosan kapcsolódó esztétikai értékek, arány és harmónia, valamint a ritmus tartozik. A tér, az idő (mozgás, folyamat, változás) ábrázolásának módjai jelentős képi szervező erőt jelentenek. A vizuális nyelvi elemek (pont, vonal, folt, forma, szín, fény) minőségeinek viszonylatai eredményezik a kifejezést, melyet az egyéni beállítódás nagyban befolyásol (Piper, 1984).

\section{A vizuális kommunikáció tanitásának helye a nevelés és a vizuális nevelés történetében}

A vizuális müvészeti nevelés szoros kapcsolatban áll az adott kor vallási, filozófiai, társadalmi rendszerével és művészetfelfogásával. A képzőművészet viszonylag későn jelent meg az iskolai tantervekben, annak ellenére, hogy már az ókori Görögországban megszületett a látási tapasztaláshoz kapcsolódó müvészi szemlélet. A 15. században a nyomtatás terjedésével a képben rögzített ismeretek széles körü terjesztésének lehetősége nyílt meg. Dürer a geometria néhány olyan fontos kérdésével foglalkozott (síkgörbék szerkesztése, szabályos sokszögek szerkesztése, térbeli alakzatok - gúlák, hasábok, hengerek - ábrázolása, testek árnyékainak megszerkesztése), melyek 300 éven keresztül meghatározták az általánosan elfogadott ábrázolási módokat, technikákat. A 16. században jelent meg az első festőmintakönyv, de a legnagyobb hatást Agostino Caracci pedagógiai tevékenysége gyakorolta a 17. században. Magánakadémiáján Leonardo elképzeléseit élesztették fel, és megjelent az akadémiai alakrajz. Az akadémiáknak szigorúan felépített tanmenete volt, a tanulás a mintakönyvek metszeteinek másolásával kezdődött. Ezek a mintakönyvek voltak tulajdonképpen az első vizuális szótárak, melyeknek használatával egységesebbé vált az európai vizuális szókincs. Az akadémiai hagyományok a 18. században megrendültek, a 19. században pedig elkezdődött az a változás, ami a 20. század dilemmáit előrevetítette (Bodóczky, 2003; Csöregh, 1991).

Az esztétikai művészetpedagógia kezdő mérföldköve John Ruskin Elements of Drawing (A rajz alapelemei) címü könyvének megjelenése volt 1857-ben. A gyermek és a müvészet kapcsolatáról szólt 1887-ben Corrado Ricci és 1888-ban Bernard Perez müve is, őket James Sully modern gondolkodást tükröző írása (Tanulmányok a gyerekkorból) 
és Julius Langbehn Rembrandt, a nevelö címü korszakalkotó könyve követte. A 19. századi Európában megkezdődő törekvések a rajztanítás kötelezővé tételére irányultak, de az alapfokú iskolákban csak a század végére lesz kötelező tárgy a rajz. A tananyagot a müszaki rajz elemei és a klasszikus müvészeti stílusok díszítményeinek másolása jelentette. William Minifie az írás elsajátításához tartotta fontosnak a rajzolást és

A 18. században a céhekben folyó képzés során némely városi tanács rendeletben kötelezte bizonyos céhek mestereit, hogy inasaikat, segédeiket ipari tanfolyamokra járassák, ahol a mesterségük végzéséhez szükséges ismereteket elsajátíthatják, fa és gipsz gépészeti, épitészeti modellekkel felszerelt rajztermekben. A vasárnapi rajziskolák megszervezése és az inasok részvétele kötelezó volt. A rajziskolát múködtetó városokban egyetlen olyan céhlegény sem válhatott mesterré, aki nem tudta bizonyitvánnyal igazolni, hogy legalább egy évig rajzoktatásban vett részt (Kornis, 1913). A korabeli rajzoktatás meghatározó módszere volt a tanári mintarajzok másoltatása, ugyanakkor a geometriai modellek oktatásban való alkal-

mazását is szorgalmazták. Pestalozzira hivatkozott, ahogyan Anglia, Franciaország és Hollandia pedagógusai is. John Dewey a rajzoktatás céljának a személyiség kibontakozását tartotta. A látást szabadkézi rajzzal fejlesztő módszert alkalmazta Flinzer és a naturalista pedagógiai iskola (Kárpáti, 1995). A 19. század utolsó évtizedétôl a gyermeki individuum önállóságáért és szabadságáért való törekvések törtek utat, a „New School” programját több európai iskola tette magáévá. Nagy szerepe volt a korszak pedagógiájának megújításában Adolf Ferriere-nek, Maria Montessorinak és Ovide Decroly-nak. Montessori az észlelést, érzékelést fejlesztő eszközökre helyezte a hangsúlyt a vizuális nevelés feladataiban. Ezek az eszközök a mindennapi életben való eligazodást segítették, $\mathrm{s}$ mint ilyenek, kommunikációs feladatokat is elláttak. A gyerekek napirendjében benne volt a kézimunka, festés, rajzolás, mintázás. A klasszikus korszak végének nagy hatású pedagógusai Karácsony, Freinet és Steiner (Trencsényi, 1999, 2005). Freinet forradalmian új iskolai esztétikai nevelést gyakorolt, a napi ihletet adó sétákat követő felolvasások közben rajzoltak és jegyzeteltek a diákok. A szabad alkotás és a különféle grafikai eljárások együttes gyakorlása után az elkészült rajzokat megbeszélték, illetve naponta kiválasztva kettőt betettek az „Élet könyvébe" vagy sokszorosították (Kárpáti, 1997). Ez a feladatsor szép példája, hogyan illeszkedett az esztétikai nevelés tárgyba a még fogalmilag nem létező vizuális kommunikáció. A két világháború közötti időszakban jelentős iskolakoncepciók alakultak, melyek közül a Steiner (1992) nevével fémjelzett Waldorf-pedagógia egyértelmủen mủvészeti neveléssel átitatott.

Hazánkban a Mária Terézia által kibocsátott Ratio Educationis az első olyan királyi rendelet, amely kísérletet tett a magyar oktatásügy állami rendezésére, a továbbtanulni nem szándékozó tanulók számára olyan készségek oktatására is hangsúlyt fektetett, mint például a szabadkézi rajz, hiszen ennek ismerete hasznos lehetett a különböző mesterségek tanulása során. A 18. században jelennek meg az első, Sárvári Pál nevéhez kötődő, magyar nyelvủ rajztankönyvek. A vizuális nevelés alatt az aktuálisnak vélt szellemi értékek elsajátítását és interpretálását tartották, ami egyet jelentett a szépre neveléssel. A 18. században a céhekben folyó képzés során némely városi tanács rendeletben kötelezte 
bizonyos céhek mestereit, hogy inasaikat, segédeiket ipari tanfolyamokra járassák, ahol a mesterségük végzéséhez szükséges ismereteket elsajátíthatják, fa és gipsz gépészeti, építészeti modellekkel felszerelt rajztermekben. A vasárnapi rajziskolák megszervezése és az inasok részvétele kötelező volt. A rajziskolát müködtető városokban egyetlen olyan céhlegény sem válhatott mesterré, aki nem tudta bizonyítvánnyal igazolni, hogy legalább egy évig rajzoktatásban vett részt (Kornis, 1913). A korabeli rajzoktatás meghatározó módszere volt a tanári mintarajzok másoltatása, ugyanakkor a geometriai modellek oktatásban való alkalmazását is szorgalmazták. A rajzoktatás korai periódusában nem választható el egymástól élesen a képi közlés két alapvető formájának (objektív, ábrázoló és szubjektív, kifejező) tanítása. Az 1861-ben kiadott rendelet, amely a tanítóképzők I-II. évfolyamán heti 2 órában tette kötelezővé a rajzoktatást, fontos fordulópont a rajzoktatás történetében, bár hatása csak később érvényesülhetett.

A rajzoktatástól a mủvészeti nevelésig hosszú út vezetett. A 20. században az alkotó, kreatív ember középpontba kerülésével párhuzamosan jelentek meg különböző reformpedagógiai gondolatok. Nagy László 1905-ben megjelent Fejezetek a gyermekrajzok lélektanából címü könyvében a gyermekek képességeiröl ír, melynek hatására az akadémiai rajztanítás elemei háttérbe szorulnak, és megindult a gyermekrajzok gyüjtése, rendszerezése (Kárpáti, 1997; Bornstein, 1997). A hatvanas évektől egymásra torlódó müvészeti áramlatok nem jutottak el az iskoláig, melynek hiánya máig nyomot hagyott a vizuális kultúra oktatásában. Ennek ellenére voltak reformpedagógiai törekvések (Kárpáti, 1988). Bak Imre és Lantos Ferenc munkássága különösen nagy hatással volt arra, hogy a rajz tantárgy átalakuljon vizuális neveléssé, amibe bekerültek a vizuális nyelv, vizuális kommunikáció, a tárgy-és környezetkultúra és mára a médianevelés elemei is. A hetvenes évek általános iskolai neveléséből hiányzó komplex szemlélet hiányát pótolta az akkor induló, ma is müködő GYIK Műhely, ahol a vizuális tevékenységekhez már kezdettől fogva társult a zene, a mozgás, a film és később a videó is. A mühely nemcsak a kreatív készségek kibontakozását tüzte ki célul, hanem azon keresztül a psziché kommunikációját is. E szimbolikus beszéd legáltalánosabb megnyilvánulása a vizuális nyelv, melynek gyakorlati használatához a képzőmüvészet eszközrendszerét használják (Hegedüs, Kalmár és Szabics, 1997; Eplényi, 2006). A müvészeti nevelés szerepeinek változásával összemosódtak a határok a müvészeti nevelés és a müvészeteken keresztül való nevelés között, a különbségtétel fontosságára Bamford hívja fel a figyelmet. A müvészeti nevelés tartalmazza a vizuális nevelést, a müvészet általi nevelés pedig más tartalmak továbbadására használja fel az elöbbiben megszerzett tudást (Bamford, 2006).

\section{Taxonómiák, frameworkök}

\section{Az értékelés a vizuális nevelésben}

A vizuális nevelés nagy részét a képzőmüvészethez kapcsolódó mütermi munka alkotja, melyben nehézkes objektív mérési rendszer kidolgozása. Nagy teret kapnak a tanár személyes nézetei, ízlése, tájékozottsága és ezekből következő szubjektív ítélete. Az objektív értékelés hiánya nagy presztízsveszteséget okoz a tantárgynak, ezért a vizuális nevelés számára alapvető fontosságú a lehető legobjektívebb értékelési rendszert kidolgozni. A rajztanárok egy része idegenkedik ettől, mert félti a művészet autonómiáját, de sokan helyeslik azt a törekvést, hogy pontosabban meghatározott követelményrendszerrel növeljék a tantárgy hatékonyságát (Kárpáti és Kovács, 2009; Gardner, 1983, 1996; Gajdics, 2003). Ezzel a problémával küzd több más európai ország is. Hazánkhoz hasonlóan Finnországban az érettségi bevezetésével nőtt a tantárgy súlya az oktatási rendszer- 
ben, Angliában 1998-tól létezik vizuális művészeti érettségi, a német tartományokban is egyike a kötelezően választható vizsgatárgyaknak a rajz. Valószínüsíthető, hogy ahol van rajzból érettségi vizsga, ott nagyobb a tantárgy presztízse, javul az oktatás szakmai színvonala is. Az USA-ban gazdasági indíttatásra óriási pénzeket költenek a művészeti nevelés fejlesztésére, mivel az USA legnagyobb exportbevétele a vizuális müveltséggel közvetlen kapcsolatban álló szórakoztatóiparból származik.

A frameworkök, tartalmi keretek megalkotása az első lépés a mérőeszközök kialakításában. Az ismeret-készség jellegű tantárgyak oktatásában az oktatási elemeket rendszerező és alkalmazhatóságukat figyelembe vevő modellek készítése nagyon rövid múlttal rendelkezik. A rajzkészség ('drawingability') standardizált értékelése a hatvanas években kezdődött az Egyesült Államokban, majd Hollandiában, Németországban, Angliában és a skandináv országokban, és folytatódik napjainkban is (Boughton és Ligtvoet, 1996; Boughton, 2004; Haanstra és Schönau, 2007). A magyar pedagógiai kutatók is csatlakoztak a kutatásokhoz: az oktatásban alkalmazható rajzi képességteszteket standardizáló nemzetközi csoportokhoz (Gerö, 1973; Feuer, 2000; Kárpáti, 2001; Csapó és Varsányi, 1985); a konstruálóképesség angliai vizsgálataihoz (Gaul, 2001; Pataki, 2012); a projektrendszerü értékelés holland és finn kidolgozóihoz (Bodóczky, 2002; Kárpáti, 1997a, 1997b). A térszemlélet (Séra, Gulyás és Kárpáti, 2002) vizsgálatai a vizuális nevelés tantárgyközi relevanciáját, a müszaki felsőoktatásra gyakorolt hatását igazolták. A vizuális képességek vizsgálatát aktualizálja az informatikai írástudáshoz szükséges vizuális képességelemek napirendre kerülése (térszemlélet, rugalmas memória, színérzékelés, képértelmezés). Egy nemzetközi projekt keretében feltárták azokat az értékelési szempontokat, amelyeket a különböző hagyományokkal rendelkező európai országok legtöbbjében érvényesnek ismernek el. Ezeknek a szempontoknak pontosan megfogalmazhatónak és számon kérhetőnek kell lenniük. A projektben az értékelhető készségeket, jártasságokat, ismereteket öt csoportba sorolták: feladatmegoldó; kommunikációs képesség; szakmai ismeretek, készségek, képességek; kreativitás; önismeret (Bodóczky, 2009), valamennyi értékelési szempont kontextusfüggö.

Az egyik legnagyobb mérés hazánkban 1988-1992-ben az öt alternatív vizuális anyagot kipróbáló Leonardo Program volt (Kárpáti, 1992). A tanulók vizuális alkotói és befogadói képességeit, mentális fejlődésük néhány mutatóját a tananyagok bevezetése előtt és a kísérleti tanítás végén tesztekkel és tesztjellegü feladatokkal vizsgálták. Kidolgoztak a kutatásban használt, vizsgáztatásra és rendszeres értékelésre, tehetségdiagnosztikára is alkalmas pedagógiai mérőeszközöket. A program válaszokat keresett arra, mi várható a vizuális neveléstöl, ha esélyt kap az iskolában, valamint mi az, amire nem alkalmasak a müvészetpedagógiai programok (Kárpáti és Gyebnár, 1996). A 2010-es A vizuális képességek értékelése TÁMOP-kutatás koncepcióját a nemzetközi és hazai szakirodalom, valamint a hazai tapasztalatok alapján Kárpáti Andrea dolgozta ki. A kutatás céljai között szerepelt a vonatkozó szakirodalom feltárása és elemzése, a magyar kultúrában érvényes vizuális képességlista elkészítése és ennek alapján értékelö feladatok készítése (Kárpáti és Gaul, 2011). Mára egyértelmüvé vált, hogy a képzőmüvészet egyedisége nem csorbul a géppel alkotott képek, a digitális kultúra, a müvészi multimédia-alkotások másolhatóságával. Új, anyagtól független értékelési szempontok jöttek létre, az esztétikai színvonal, a gondolati tartalom, a kreatív kompozíció bármely módon megnyilvánulhat.

A vizuális ismeretek alapvetően procedurális jellegü tudást feltételeznek, a mértékadó kutatók szerint egyedi müvek születnek, melyeket a tanár és a diák közötti párbeszédben megvalósuló értékeléssel lehet csak minősíteni (Freedman, 2010). A portfólió-értékelés, az alkotói munkanapló szövegével összevethető müvek értékelése, zsürizése ugyanolyan megbízható értékelési kritérium, mint a tesztelés (Kárpáti és Gaul, 1998). Magyarországon mára a portfólió-értékelés beépült az érettségi vizsgáztatásba (Kárpáti, 1997a; 
Kárpáti és Gaul, 1998; Pallag, 2006), a portfóliók a legjobb, az átlagos és a gyenge megoldásokat tartalmazzák az érettségiző diák munkái közül, melyekből megbízható értékelési segédeszköz fejleszthető. A Nemzetközi Rajzi Érettségi (International Baccalaureate Program in Art Education) ugyanezt a vizsgáztatási módot alkalmazza. Az 1954-ben kidolgozott, jól körülhatárolt Bloom-taxonómia alkalmazása nagy elörelépést jelenhetne a tantárgy követelményrendszerének kidolgozásában.

\section{A vizuális kultúra tantárgy helyzete, a vizuális kommunikáció helye a rajz- vizuális kultúra tantárgy kereteiben, tantervi célok és követelmények}

A 17. századi jezsuita kolostori iskolákban szépírásra, zenére, geometriára, rajzra, építészetre tanították rendjük ügyes kezü tagjait. Az 1783-ban kiadott királyi rendelet elöírta a vasárnapi rajziskolák felállítását, melyek látogatását kötelezővé tette az inasok számára, valamint a müszaki pályára készülő elemi iskola negyedik osztályos tanulói számára is kötelezővé tette a rajztanítást (Kornis, 1913). Ez a rendelet tekinthető a rajzoktatás első tantervének, „vezérkönyvének”, mely szabályozta a rajzoktatás tartalmát és az alkalmazandó oktatási módszereket is. A Nemzeti Alaptanterv megjelenéséig a rajztantervekben az építészet és a képzőmüvészet tanítása szerepelt, 1995-től a tantárgy neve Vizuális kultúra lett. A NAT a világ legkorszerübb pedagógiai modelljét a hasonló tartalmú amerikai és német tantervi reformokkal egy időben honosította meg (Bodóczky, 2003; Pallag, 2006), ez országos módszertani reformot eredményezett Magyarországon. A Vizuális kultúra műveltségterületének anyagában a képzőmüvészet mellett a környezetkultúra és a vizuális kommunikáció is megjelent. A tantárgy alkalmazkodott a 20. században eltűnő homogén korstílus kihívásaihoz, tananyagába egyaránt beleférnek Leonardo gondolatai, az akadémizmus és a közösségi háló informatikai alkalmazásai. Az új tantárgy az esztétikai minőséget másodlagosként határozza meg, újraértelmeződik az oktatás lényege: a hangsúly az alkotó folyamatra, az egyéni alkotóképességre, a kreatív vizuális nyelvhasználatra kerül, amely egyszerre tanulságos és katartikus az egyén számára (Csíkszentmihályi, 1988; Souza, 1998; Steers, 2009; Freedman, 2010, Harten, 1996). A vizuális kultúra műveltségterület oktatója a hagyományos képi nyelv megértése és használata mellett az önkifejezés egyre újabb útjait is tanítja. Hazánkat is érintette a környezettudatos gondolkodás szele, a mindennapi élet vizuális problémáira fókuszáló, környezettudatos „öko-müvészeti nevelés”, ami elsősorban Európa északi felén, Németországban, Hollandiában és Kanadában hódít (Freedman, 2003). Az angol és a német vizuális nevelés jellegzetessége, hogy a fogyasztói nevelés és a társadalmi érzékenység fejlesztésében rendkívül fontos vizuális kommunikációval kiemelten foglalkozik. Napjainkban a Vizuális kultúra a legelterjedtebb rajzpedagógiai irányzat. A vizuális nevelés leggyakoribb módszerei a posztmodern vizuális nevelési modell (Milbrandt, 1998), az integratív esztétikai nevelés (Kárpáti és Gaul, 1998), valamint a multikulturális müvészetpedagógia.

Az aktuális kerettantervben a vizuális kommunikáció a vizuális kultúrán belül külön területként jelenik meg, bár az első két iskolai évben háttérbe szorul. Az új kerettanterv sokkal nagyobb hangsúlyt fektet a vizuális információk befogadására, értelmezésére, tudatosítására, mint a NAT. A képességek konkrétabban jelennek meg, új elemként beépül a média a tantárgyba:

„A tantárgy fontosságát hangsúlyozza, hogy az információs csatornák gazdagodása a szöveges információ befogadása mellé felzárkóztatja a vizuális információk tudatos befogadásának fontosságát is, hisz az információk forrása és jellege alapján szöveg és kép együttes értelmezése napjainkban gyakoribb jelenség valós élet- 
helyzetekben. A médiatudatosság fejlesztésének tehát egyre fontosabb aspektusa már ebben az iskolaszakaszban is a vizuális megfigyelés és értelmezés segítségével megvalósuló médiahasználat és médiaértés."

A Mozaik Kiadó által megjelentetett, illetve az oktatási miniszter által a 10/2003. (IV.28.) számú rendeletben kiadott kerettanterveket ${ }^{2}$ vizsgálva kijelenthető, hogy a vizuális felismerés, értelmezés, elemzés minden tantervben, de változó hangsúllyal szerepel. A dekódolás és percepció kap nagyobb szerepet, kódolásról ritkábban esik szó. Mivel a 2012-es kerettantervekben nagy mértékben helyet kapott a média, belépett a képalkotás közé a fotózás, valamint a hang-kép transzformáció. Az új média megjelenése nagy teret kaphat az esélyegyenlőség megteremtésében. Alig, vagy egyáltalán nem jelenik meg a tantervekben a forma- és arányérzék, a verbális-nonverbális és a vizuális kommunikáció kapcsolata. Mindegyik tantervben különböző hangsúllyal és elvárásokkal, de jelen lévő tartalom az ábrák, ábrázolások felismerése, komponálás, a vizuális dinamika felismerése, a szimbolizáció, a szó-kép, illetve a kép-szó leképezés. A vizuális kommunikáció tárgykörébe nem emeli be a képzőmüvészeti alkotásokat, következetesen csak az ábrákra szükíti a megismerési folyamatokat, ami nincs egyensúlyban a kognitív pszichológia eredményeivel (Sekuler és Blake, 2000; Goodman, 1977). Bár a képzőművészet nem kommunikáció, de az észlelés minőségének meghatározottságával a képzőművészeti alkotások beemelhetők a kommunikáció elemei közé. Szigorúan vett követelményeket egyik tanterv sem határoz meg, csak remélt eredményeket.

Összességében elmondható, hogy a magyar vizuális nevelés hagyományosan alkotás-orientált, amelyben a diákok elsősorban az alkotó folyamat során szereznek befogadói élményeket. Csíkszentmihályi (2010) a minden emberben rejlő alkotóképesség kibontakoztatását hangsúlyozza, az alkotás esztétikai minősége szerinte másodlagos, az alkotófolyamat a lényeg. Nagy József rendszerében, a kortárs magyar művészetpedagógia felfogásával összhangban, a vizuális önkifejezési képesség fejlesztése az alkotásban jelenik meg (Nagy, 2000; Bodóczky, 2003). Az önálló befogadás képességének fejlesztése, lehetőségeinek feltárása azonban további kutatásokat igényel.

\section{Vizuális képességek kutatása, mérése és fejlődése 6-12 éves korban}

\section{A vizuális képesség fejlödési modelljei}

Az 1887-ben megjelent első, gyermekrajzokról szóló mű szerzője, Ricci, művészettörténész volt. Szerinte a gyermekrajz fejlődése a müvészettörténeti korszakok stílusainak változását ismétli meg. A képi ábrázolás fejlődését Ricci óta sokan kutatták és modellezték, így Kerschensteiner (1905); Rouma (1908); Burt (1921); Luquet (1927); Lowenfeld (1947); Kellog (1967). A gyermekkori rajzolás, a képi gondolkodás a vizuális képességek fejlesztésén kívül hatékony szerepet játszik az általános értelmi képességek, a kognitív gondolkodás fejlődésében. Kepes György (1979) a müvészeti oktatást szélesebb társadalmi közegben szorgalmazta, mert álláspontja szerint a képi gondolkodás strukturálja és alakítja a külvilágból érkező jeleket értelmes dolgokká. Arnheim az érzékelés és az absztrakt gondolkodás egységét hangsúlyozta, ami szerint a gondolati müveletek nemcsak szavakkal és számokkal történő müveletekből állnak, hanem szerves részt alkot benne a képi gondolkodás is. Piaget $(1978,1999)$ kutatásai alapján a gondolkodás fejlődése egyszerre több területen jelenik meg: beszédkészség, zenei hallás és kifejezés, alak, forma és térlátási készségek, rajzi ábrázolás készsége, szimbolikus közlés készsége, stb.

A vizuális képességek modellezését két szempontrendszer szerint lehet vizsgálni, mindkettőt meghatározza a célja. Az egyik a lélektani és mentális jelenségeket, fizikai 
fejlődési sajátosságokat kutató ág (Gerő, 1973, 1981, 1983; Feuer, 2000; Hárdi, 2002; Vass, 2006), a másik szempontot pedig az alkotói-befogadói képességrendszer egész fejlődését nyomon követő, pedagógiai célú értékelés jelenti (Székácsné, 1982; Kárpáti, 2001).

\section{Rajzfejlődés-elméletek}

Gesell már 1925-ben regisztrálta a fejlődés szekvenciáit a geometriai formák másolásának képességében: 2-3. év: horizontális vonal; 3-4. év: négyszög; 5-6. év: háromszög; 7-9 év: csúcsán álló négyszög, felosztott téglalap. A rajzolt emberalak színvonalából kb. 10 éves korig lehet következtetéseket levonni a rajzoló intellektuális szintjére vonatkozóan. Erre a gondolatra épül az 1926-ban, Goodenough által kidolgozott emberrajz-teszt. A Goodenough-tesztről széles körü viták folytak, de egyetértés van abban, hogy bizonyos keretek között mégis informatív lehet, mert a megfelelö lelkiállapotban lévő gyerekek a „Rajzolj egy embert!” instrukcióra elsősorban intellektuális erőiket mobilizálják, így a rajz diagnosztizálásra és terápiára is alkalmassá vált. Piaget $(1978,1999)$ konstruktivista megközelítése szerint a gyerekek rajzolásának fejlődése szakaszos, a gyerek a rajzolt tárgy egyre több vonatkozását ábrázolja az egymást követő szakaszokban. A modularista álláspont szerint, habár a rajzolási képesség normális fejlődéskor különböző szakaszokon megy keresztül, néhány lényeges kivétel azt sugallja, hogy a rajzolás különálló kognitív terület. Selfe (1983) több olyan gyereket is talált, akiknek a nyelvi képessége és az általános értelmi szintje alacsony volt, viszont a grafikus ábrázolásban kivételes képességet mutattak. Mindez annak a bizonyítéka, hogy az olyan mentális modulok, mint a nyelv és az észlelés, egymástól viszonylag függetlenül fejlődhetnek. Gardner $(1983,1996)$ olyan gyerekekről számolt be, akiktől kisgyermekkorukban megvonták a rajzolás lehetőségét, és amikor megint rajzolhattak, akkor átugrották a kezdeti szakaszokat. Ezek a példák ellentmondanak a piaget-i álláspontnak. A kulturális megközelítés szerint a rajzolás képességeinek fejlődése kontextusfüggő. A fejlődés függ a gyakorlás mértékétől és a gyermeket körülvevő felnőttek reakcióitól. A rajzfejlődés szakaszainak időhatárai kultúrafüggők, a távol-keleti kultúrákban például mások a fejlődési korszakok, mint Európában.

\section{A 6-12 éves szakasz jellemzöinek összegzése}

A 6-10 éves szakasz első felében (7-8 éves korig) elsősorban érzelmekkel közelítenek a gyerekek a megismerés felé, de kezd az intellektus is megnyilvánulni. A transzparencia 7-8 éves korig nö, majd csökken és 10 éves korra eltünik. A képek veszítenek fantasztikumukból, az érzelmi feszültség megszűnése jellemző. Finomodik a kézmozgás, fejlödik az analizáló, szintetizáló képesség, nő az egyéni motívumkészlet és a kompozíciós repertoár. Két típusú rajzoló gyermeket különböztethetünk meg. Az egyik a szintetizáló, aki az egészet emeli ki a környezetből, egy-egy érdekes részletet hangsúlyozva kontúrral, aprólékos megjelenítéssel. A másik az analizáló, akit a szerkezet, a felépítés köt le. Ebben a korszakban válik a rajz jellé, erős szkematizálás figyelhető meg.

A 9-12 éves kori szakaszban bekövetkező „rajzi törés” valójában nyelvváltás. A kortársak hatása egyre nagyobb, megnő a realista ábrázolás, az emberrajz kifejezi az életkort, a nemet, a hangulatot, a kulturális környezetet. Ebben a szakaszban sajátítják el a gyerekek a tér- és színábrázolási konvenciókat. Ezek a sajátosságok meghatározzák a pedagógiai kereteket, módszereket. Az érzelemben gazdag, életből vett témák nagyobb motivációt jelentenek, megnő a csoportmunka jelentősége. A digitális eszközök széles 
körü elterjedése előtt a vizuális nyelv háttérbe szorulása jellemző a verbálissal szemben. A könnyen hozzáférhetö, inspiráló, rugalmas képalkotó technikák bővülésével és mindennapokba emelésével a korosztály képalkotó kedve nem csökken, sőt, a képekkel történő énkifejező tevékenység és kommunikáció nő. A vizuális nyelv a közlés természetes módja, mely nyelv megértéséhez a klasszikus müvészeti értékek helyett a kortárs alkotók stílusirányzatai és közlésmódjai segítenek (Kárpáti és Gaul, 2010).

\section{A vizuális aktivitás képességrendszere és a vizuális kommunikáció képességcsoportjának rendszere}

A tanult vizuális kommunikációban kiemelt jelentősége van az egyéni képességeknek. A vizuális kommunikációhoz elengedhetetlen a percepció és az appercepció képessége. A percepció ebben az esetben ,a vizuális érzékelésnek és észlelésének az a sajátos képessége, amikor látvány nonfiguratív optikai alakzataiban tanult esztétikai képzeteink segítségével, egyszerübben szólva pl. szépségképzeteink segítségével szépségre vélünk ismerni" (Bálványos és Sánta, 2003, 99. o.). Az appercepció a vizuális gondolkodás, az alkotó esztétikai látás képessége. A vizuális kommunikáció folyamataiban együtt van a megismerés, gondolkodás és az alkotás, kreativitás (Bálványos és Sánta, 2003). A tanult vizuális kommunikációba a vizuális befogadóképességek és a vizuális alkotóképességek tartoznak. Az ember vizuális befogadó tevékenysége kiterjed a teljes látható világ befogadására a hétköznapi tárgyaktól a természeti képeken át a müalkotásokig, illetve a vizuális észlelés nem közvetlenül a szem ingerfelvevő funkciójában történő területére is. A vizuális alkotó tevékenység minden látható, ember által készített tárgy, kép (függetlenül annak tárgyától és anyagától; azaz akár szellemi dimenzionáltsága is lehet, mint a konceptualista törekvések esetében, ld. Kosuth, 1965: One and Three Chairs) megvalósítására irányuló tevékenység. Az alkotás és befogadás kérdéseivel a kognitív pszichológia foglalkozik, valamint a müvészetpszichológia és müvészetelmélet.

A magyar kutatók élen járnak a vizuális képességek feltárásában (Kárpáti, 2013). A 2011-ben zárult, vizuális képességeket vizsgáló kutatás keretében a szakértő csoport összeállított egy framework jellegű, a vizuális képességrendszert lefedő, tizenkilenc képességelemből álló struktúrát (Pataky, 2012). Bármely képességelem feltárása képességcsaládok feltárását jelenti, ebben a rendszerben különálló képesség-alrendszerként jelenik meg a vizuális befogadó képesség, melynek vizsgálatára külön feladatsorokat terveztek. A rendszert a napi iskolai értékelési gyakorlatban való használhatósága érdekében egyszerüsítették. Hipotetikus képességcsoportokat képeztek, feltételezve, hogy a vizuális kompetencia négy fö klaszterben írható le:

1. Vizuális megismerés (észlelés, emlékezés, értelmezés) / tanulási képességek

2. Ábrázolási konvenciók, technikák használata

3. Vizuális alkotó, kifejező képesség

4. Vizuális kommunikációs képesség

Valamennyi vizuális képesség beilleszthető a négy klaszter valamelyikébe. A rendszerben a vizuális kommunikáció képességcsoportjába a következő képességek tartoznak: konstruálás; anyagalakítás, eszközhasználat; ábrák alkotása és értelmezése; nem vizuális jellegü információk megjelenítése; időbeli folyamatok megjelenítése. A vizuális kommunikáció képességcsoportjának elemei mindegyik klaszterrel kapcsolatban állnak. A vizuális kommunikáció képesség-frameworkjét 11 képességelem alkotja (Babály, Kárpáti és Simon, 2015, megjelenés alatt). 


\section{Összegzés}

A tanulmányban megpróbáltam összegezni a vizuális kommunikáció tudományával foglalkozó elméleteket, a kommunikáció diszciplínájába való beágyazódását, a vizuális kommunikáció meghatározásának sokoldalú megközelítéseit, melyek rávilágítanak a terület kutatásának aktualitására és lezáratlanságára. A vizuális kommunikáció definiálása aszerint változott a fogalom megjelenése óta, hogy a vizualitásra vagy a kommunikációra helyeződött a hangsúly. A digitalizációval egységes formára hozhatók a különböző kommunikációs csatornák, felborul a hagyományos képfogalom, új etikai problémák vetődnek fel (plágium, közkincs, szellemi tulajdon), mely folyamatok megkövetelik a nyelvi és a képi kommunikációról való gondolkodás új alapokra helyezését. A vizuális kommunikáció tartalmainak és még inkább az új média és a számítógép megjelenésével bővülő vizuális nyelvi elemek, a digitális képalkotás és befogadás folyamatainak további feltárására, valamint a kognitív pszichológia eredményeinek a vizuális kommunikáció értelmezésébe való alaposabb beágyazására van szükség, amennyiben a hozzá kapcsolódó képességeket szeretnénk vizsgálni. A vizuális képességfejlesztés és a vizuális nevelés kognitív területekre gyakorolt hatását kutatások bizonyították, transzferhatása az affektív tényezőkre empirikus úton egyértelműen alátámasztható. A vizuális nyelv ismerete és alkalmazása az esélyegyenlőség eszköze. A perceptuális tanulás és a vizuális készségek, képességek kölcsönös kapcsolatban vannak, mely kapcsolat a gondolkodás új aspektusai felé nyit kaput. A vizuális kommunikációs képességek, mint a vizuális alkotó- és befogadó képességek egyik klasztere jelenik meg a legújabb kutatásokban, szoros összefüggésben a többi klaszterrel. Ezen képességek magukba foglalják a konstruálás, anyagalakítás, eszközhasználat, ábrák alkotásának és értelmezésének, a nem vizuális jellegü információk megjelenítésének és az időbeli folyamatok megjelenítésének képességét. Az egyensúly megteremtése a képességrendszer, az önálló befogadás képességének fejlesztése és lehetőségei, a taxonómiák, valamint a vizuális kommunikáció tartalmai között a jövő feladata.

\section{Jegyzetek} ${ }^{1}$ http://kerettanterv.ofi.hu/alt_isk_also/index_alt__
isk_also.html

\section{Irodalomjegyzék}

Achen, S. T. (1981): Symbols Around Us. Van Nostran Reinhol Company, London.

Antik Sándor (2010): Vizuális megismerés és kommunikáció. Egyetemi Műhely Kiadó, Kolozsvár.

Arnheim, R. (2004a): A vizuális élmény. Gondolat Kiadó, Budapest.

Arnheim, R. (2004b): Az alkotó látás pszichológiája. Aldus Kiadó, Budapest.

Babály Bernadett, Kárpáti Andrea és Simon Tünde (2015, megjelenés alatt): A vizuális képességrendszer elemeinek értékelése: térszemlélet és képi kommunikáció. In: Csapó Benő és Zsolnai Anikó (szerk.): Online diagnosztikus mérések az iskola kezdö szakaszában. Szeged.
Bakos Tamás, Bálványos Huba, Preisinger Zsuzsa és Sándor Zsuzsa (2000): A vizuális nevelés pedagógiája. Balassi Kiadó, Budapest.

Bálványos Huba és Sánta László (2003): Vizuális megismerés, kommunikáció. Balassi Kiadó, Budapest.

Bamford, A. (2006): The Wow Factor: Global Research Compendium on the Impact of the Art sin Education. Waxmann, Münster - New York - Berlin.

Bätschmann, O. (1998): The Artist in the Modern World: The Conflict Between Market and SelfExpression. DuMont Buchverlag, Köln.

Baudrillard, J. (1987): A tárgyak rendszere. Gondolat Kiadó, Budapest. 
Benkőné Zsemlye Erzsébet (1964): Adatok 4-8 éves gyermekek személyiségvizsgálatához rajzvizsgálatok alapján. A Goodenough-féle teszt hazai alkalmazhatósága. In: Pszichológiai Tanulmányok. VI. Akadémiai Kiadó, Budapest. 575-593.

Bodóczky István (2002a): A rajz, vizuális kultúra tantárgy helyzete és fejlesztési feladatai. Új Pedagógiai Szemle, 52. 10. sz. 59-72.

Bodóczky István (2002b): A rajz, vizuális kultúra tantárgy helyzetének elemzése. Kézirat. Országos Közoktatási Intézet, Budapest.

Bodóczky István (2003): A vizuális nevelés megújítása, új paradigmája. Új Pedagógiai Szemle, 53. 7-8. sz. $35-43$.

Bodóczky István (2009): Áthallások Transzdiszciplináris vizuális nevelés. Iránypont, Különszám. Moholy-Nagy Művészeti Egyetem. Budapest.

Bornstein, M. H. (1997): A gyermek, mint művész és közönség. In: Farkas András (szerk.): Vizuális müvészetek pszichológiája 2. Nemzeti Tankönyvkiadó, Budapest. 325-341.

Boughton, D. és Ligtvoet, J. (1996): Evaluating and assessing the visual arts in education: International perspectives. Teachers College Press, Boston.

Boughton, D. (2004): Assessing art learning in changing contexts. In: Eisner, E. és Day, M. (szerk.): Handbook of research and policy in art education and evaluation. Laurence Erlbaum, New York. 585606.

Burt, C. (1921): Mental and Scholastic Test. P. S. King and Son, London.

Csányi Vilmos (1994): Viselkedés, gondolkodás, társadalom: etológiai megközelítés. Akadémiai Kiadó, Buda-pest.

Csányi Vilmos (2006): A kommunikációs kényszer. Magyar Tudomány, 4. sz. 393.

Csányi Vilmos (2013 ): Kreatív kommunikáció. Magyar Szemle, Új folyam, 15. 11-12. sz. 2013. 10. 11-i megtekintés, http://www.magyarszemle.hu/ cikk/20061101_kreativ_kommunikacio 1

Csapó Benő és Varsányi Zoltán (1985): A rajzkészség fejlettségének vizsgálata középiskolai tanulóknál. Acta Univ. Szeg. de A. J. nom. Sectio Paed. et Psych. Ser. Spec. Paed. Szeged.

Csíkszentmihályi Mihály (1988): Society, Culture, and Person: A Systems View of Creativity. In: Stemberg, R. (szerk.): The Nature of Creativity: Contemporary Psychological Perspectives. Cambridge University Press, Cambridge. 325-339.

Csíkszentmihályi Mihály (2010): Flow - Az áramlat. A tökéletes élmény pszichológiája. Akadémiai Kiadó, Budapest.

Csőregh Éva (1991): Rajzoktatásunk története. Magyar Rajztanárok Országos Egyesülete, Budapest.
Duchowski, A. T. (2007): Eye Tracking Methodology. Springer, London. DOI: 10.1007/978-1-84628-609-4

Eco, U. (1998): A tökéletes nyelv keresése. Atlantisz, Budapest.

Elkins, J. (2003): Visual Studies. A Skeptical Introduction. Routledge, New York - London. DOI: 10.4324/9780203700587

Eplényi Anna (2006, szerk.): Kis GYIK könyv. V-Print Kiadó, Budapest.

Feuer Mária (2000): A gyermekrajzok fejlődéslélektana. Akadémiai Kiadó, Budapest.

Freedman, K. (2003): Teaching Visual Culture. Teachers College Press, New York.

Freedman, K. (2010): Rethinking Creativity; A Definition to Support Contemporary Practice. Art Education, 63. 2. sz. 8-15.

Gajdics Sándor (2003): A személyiség szocializációja és az értékelés összefüggései. Fejlesztö Pedagógia, 13. 2-3. sz. 41-47.

Gardner, H. (1983): Artful scribbles. Harvard University Press, Boston.

Gardner, H. (1996): The Assessment of Student Learning in the Arts. In: Boughton, D., Eisner, E. W. és Ligtvoet, J. (szerk.): Evaluation and Assessment of Visual Arts Education: International Perspectives. Teachers College Press, New York. 131-155.

Gaul Emil és Kárpáti Andrea (1998): A tervezőképesség értékelése projekt módszerrel 12-16 éves tanulók körében. In: Varga Lajos és Budai Ágnes (szerk.): Közoktatás-kutatás 1996-1997. Müvelődési és Közoktatási Minisztérium, Budapest. 321-349.

Gaul Emil (2001): A tervezö-konstruáló képességek szerkezete és fejlődése 12-16 éves korban. PhD-értekezés. Kézirat. ELTE Neveléstudományi Doktori Iskola, Budapest.

Gerő Zsuzsa (1981): Informatív elemek változása a rajzfejlődés folyamán. Magyar Pszichológiai Szemle, 22. 4. sz. 342-357.

Gerő Zsuzsa (1983a): A gyermekkori esztétikus rajzolás hatása a kreativitás további fejlődésére. Magyar Pszichológiai Szemle, 24. 3. sz. 244-255.

Gerő Zsuzsa (1983b): Esztétikusan rajzoló gyermekek kreativitásának követése serdülőkorig. In: Mátrai László, Bánhidi Mária és Gál Piroska (szerk.): Kreativitás és deviáció. Akadémiai Kiadó, Budapest. 45-57.

Gerő Zsuzsa (2007): Gyermekrajzok esztétikuma. Flaccus Kiadó, Budapest.

Gombrich, E. H.(1999): Miröl szólnak a képek? Beszélgetések müvészetröl és tudományról. Balassi Kiadó - Tartóshullám, Budapest.

Goodman, N. (1977): When is art? In: Perkins és Leondar (szerk.): The arts and cognition. The Johns Hopkins University Press, Baltimore. 11-19. 
Gulyás János, Kárpáti Andrea és Séra László (2002): A térszemlélet. Comenius Oktató és Kiadó Bt., Budapest.

Haanstra, F. és Schönau, D. (2007): Evaluation Research in Visual Arts Education. In: Bressler, L. (szerk.): International Handbook of Research in Arts Education. Springer Netherlands, Amsterdam. 427444. DOI: http://dx.doi.org/10.1007/978-1-40203052-9

Hárdi István (2002): Dinamikus rajzvizsgálat. Medicina, Budapest.

Harnad, S. (2001): Creativity: Method or Magic? University of Southampton, Department of Electronics and Computer Science; Intelligence, Agents and Multimedia Group, Harnar E-Print Archives. 2012. 12. 12-i megtekintés, http://cogprints.org/1627/1/ harnad.creativity.html

Hegedűs Miklós, Kalmár István és Szabics Ágnes (1997, szerk.): A nagy GYIK könyv - Kézikönyv a vizuális neveléshez. Aula Kiadó, Budapest.

Horányi Özséb (2003a, szerk.): Kommunikáció I. A kommunikatív jelenség. Kommunikáció II. A kommunikáció világa. General Press Kiadó, Budapest.

Horányi Özséb (2003b, szerk.): A sokarcú kép. Budapest, Typotex.

Horányi Özséb (2006): Jel, jelentés, információ, kép. General Press Kiadó, Budapest.

Infante, D. A., Rancer, A. S. és Womack, D. F. (1991): Building Communication Theory. Waveland Press Inc., Illinois.

Ivins, Jr., W. M. (2001): A nyomtatott kép és a vizuális kommunikáció. Enciklopédia Kiadó, Budapest.

Jensen, K. B. (2003): A kommunikáció ismeretelméleti és lételméleti szempontból. In: Horányi Özséb (szerk.): Kommunikáció I. A kommunikatív jelenség. General Press Kiadó, Budapest. 170-208.

Kárpáti Andrea (1988): Tantárgy-integráció az esztétikai nevelésben. Tankönyvkiadó, Budapest.

Kárpáti Andrea (1991): Látni tanulunk. Akadémiai Kiadó, Budapest.

Kárpáti Andrea (1992): Leonardo Program - a vizuális nevelés öt modellje. Akadémiai Kiadó, Budapest.

Kárpáti Andrea (1995a, szerk.): Bevezetés a vizuális kommunikáció tanitásához. Nemzeti Tankönyvkiadó, Budapest.

Kárpáti Andrea (1995b, szerk.): Vizuális képességek fejlódése. Nemzeti Tankönyvkiadó, Budapest.

Kárpáti Andrea és Gyebnár Viktória (1996): A vizuális képességek pedagógiai és pszichológiai mérésének összefüggései a Leonardo Programban. ELTE és Pro Educatione Gentis Hungariae Alapítvány, Budapest.

Kárpáti Andrea (1997a): Vélemények a vizuális kultúra alapműveltségi vizsga általános követelményeiröl. Új Pedagógiai Szemle, 47. 5. sz. 117-124.
Kárpáti Andrea (1997b): Vizuális nevelés: projekt módszerü vizsga. Calibra Kiadó, Budapest.

Kárpáti Andrea (2001): Firkák, formák, figurák - a vizuális nyelv fejlödése a kisgyermekkortól a kamaszkorig. Dialóg Campus Kiadó, Budapest.

Kárpáti Andrea (2005): Kamaszok vizuális nyelve. Akadémiai Kiadó, Budapest.

Kárpáti Andrea és Kovács Antalné (2009): Kommunikáció, technika, kreativitás: egy komplex mérőeszköz a vizuális képességek értékelésére. Új Pedagógiai Szemle, 59. 5-6. sz. 40-59.

Kárpáti Andrea és Gaul Emil (2010): A gyermekrajztól a vizuális kommunikációig - egy képességrendszer iskolai fejlődésének vizsgálata 6-12 éves korban. In: Csíkos Csaba és Kinyó László (szerk.): $U_{j}$ törekvések és lehetöségek a 21. századi neveléstudományokban. Zárókötet. X. Országos Neveléstudományi Konferencia. 2010. november 4-6. MTA Pedagógiai Bizottsága, Budapest. 100 .

Kárpáti Andrea és Gaul Emil (2011): A vizuális képességrendszer: tartalom, fejlödés, értékelés. In: Csapó Benő. és Zsolnai Anikó (2011, szerk.): Kognitiv és affektív fejlödési folyamatok diagnosztikus értékelésének lehetöségei az iskola kezdö szakaszában. Budapest, Nemzeti Tankönyvkiadó, Budapest. 41-82.

Kárpáti Andrea (2013): „Gyermekrajz” a 21. században: egy új fejlődéselmélet felé. In: Molnár Gyöngyvér és Korom Erzsébet (szerk.): Az iskolai sikerességet befolyásoló kognitiv és affektiv tényezök értékelése. Nemzedékek Tudása Tankönyvkiadó Zrt., Budapest. 105-122.

Kellog, R. (1967): Child Art Collection. Microcard Editions, Inc., Washington.

Kellogg, R. (1969 ): Analysing Children's Art. National Press Book, Palo Alto.

Kepes György (1965): A világ új képe müvészetben és tudományban. Corvina, Budapest.

Kepes György (1979): A látás nyelve. Gondolat Kiadó, Budapest.

Kerschensteiner, D. G. (1905): Die Entwicklung der zeichnerischen Begabung. Gerber, München.

Kince, E. (1982): Visual puns in design, WatsonGuptil Publications, New York.

Király Jenő (1992): A hétköznapiság esztétikája. Tankönyvkiadó, Budapest.

Kornis Gyula (1913, szerk.): Ratio Educationis. I-II. Az 1777-iki Ratio Educationis. Katholikus Középiskolai Tanáregyesület, Budapest.

Kunt Ernő (2003): Az antropológia keresése. Válogatott tanulmányok. MTA Néprajzi Kutatóintézet és L'Hartmann Könyvkiadó, Budapest.

Langbehn, J. (1890): Rembrandt als Erzieher Hirschfeld. Leipzig. 2013. 11. 23-i megtekintés, 
file:///C:/Users/User/Documents/Rembrandt $\% 20$ als\%20Erzieher.pdf

Löwenfeld, V. (1970): Creative and Mental Growth. The Macmillan Company, New York.

Luquet, D. H. (1913): Les dessins d'un enfant. F. Alcan, Paris.

Mendelowitz, D. M. (1954): Children are artists: An introduction to children's art for teachers and parents. Stanford University Press, Stanford.

Miklós Pál (1980) Kép és kommunikáció. MUOSZ Oktatási Igazgatósága, Budapest.

Miklós Pál (1995): Vázlat egy vizuális szemiotikához In: Kárpáti Andrea (szerk.): Bevezetés a vizuális kommunikáció tanitásához. Nemzeti Tankönyvkiadó, Budapest. 60-73.

Milbrandt, M. K. (1998): Postmodernism in Art Education: Content for Life. Art Education, 51. 6. sz. 47-53. DOI: $10.2307 / 3193752$

Mirzoeff, N. (1999): Visual Culture. Routledge, New York.

Nagy László (1905): Fejezetek a gyermekrajzok lélektanából. Singer és Wolfner, Budapest.

Nagy József (2000): XXI. század és nevelés. Osiris Kiadó, Budapest.

Nemzeti Alaptanterv (2012) Oktatási Minisztérium, Budapest.

Neumann László (1989): Képhiba. Új képkorszak határán - a számitógépes grafika és animáció kezdetei Magyarországon. Számalk, Budapest.

Neurath, O. (1980): International Picture Language. Keganpaul - Trench - Trubner \& Co. Ltd., London.

Nyíri Kristóf (2000a): A 21. század filozófiája felé. Elöadás a Filozófia az ezredfordulón c. konferencián, MTA Filozófiai Kutatóintézet, Kecskemét. http:// www.phil-inst.hu/projects/kecske.met/nyiri_21.htm

Nyíri Kristóf (2000b): A gondolkodás képelmélete. Előadás az ELTE BTK Filozófiai Intézete és Nyelvfilozófiai Kutatócsoportja Nyelv, megértés, interpretáció - A nyelv mint a kortárs filozófiai áramlatok közös problémája c. konferenciáján, 2000. október. 5-6. 2006. 09. 06-i megtekintés, HUNFI Oktatás- és Tananyagfejlesztő Szolgáltató Kft., http://www.hunfi. hu/nyiri/ELTE 2000 conf.htm

Nyíri Kristóf (2002): Képek, mint eszközök Wittgenstein filozófiájában. Világosság, 41. 1. sz. 5-21.

Nyíri Kristóf (2008): A tanulás filozófiája a mobil információs társadalomban. In: Benedek András: Digitális pedagógia-tanulás IKT környezetben. Typotex Kiadó, Budapest. 52-83.

Paál Ákos (1977): Gyermekrajzok esztétikai minőségei 6-12 éves korban. Magyar Pszichológiai Szemle, 18. 5. sz. $495-504$.
Pallag Andrea (2006): A megújult érettségi vizsga lehetőségei a rajz és vizuális kultúra tantárgy számára. In: Horváth Zsuzsanna és Lukács Judit (szerk.): $U_{j}$ érettségi Magyarországon. Országos Közoktatási Intézet, Budapest. 279--294.

Pataky Gabriella (2012): Vizuális képességek fejlődése 6-12 éves korban, a tárgykultúra területén. ELTE TÓK, Budapest.

Perez, B. (1888): L'art et la poesie chez l'enfant. Felix Alcan, Paris.

Peternák Miklós (1992): A kép a camera obscurától a computerig. In: Kárpáti Andrea (szerk.): Bevezetés a vizuális kommunikáció tanításába. Nemzeti Tankönyvkiadó, Budapest. 47-59.

Peternák Miklós (1993): Új képfajtákról. Intermédia - Balassi Kiadó, Budapest.

Piaget, J.(1978): Szimbólumképzés a gyermekkorban. Gondolat, Budapest.

Piaget, J. (1999): Gyermeklélektan. Osiris Kiadó, Budapest.

Piper, D. (1984): A müvészet élvezete. Helikon Kiadó, Budapest.

Ricci, C. (2008): L'arte dei bambini. Armando Editore, Róma

Róka Jolán (2002): Kommunikációtan. Fejezetek a kommunikáció elméletéből és gyakorlatából. Századvég Kiadó, Budapest.

Ruhrberg, K., Schneckenburger, M., Fricke, C. és Honnef, K. (2005): L'art au XX.e siecle. Tachen, Köln.

Rusbult, C. E. (1995): Visual thinking and visualverbal communication. American Scientific Affiliation. 2013. 05. 12-i megtekintés, http://www. asa3.org/asa/education/teach/visual.htm

Ruskin, J. (2010 [1857]): The Elements of Drawing. Aquitaine Media Corp., Stanford.

Searle, J. R. (2003): A képi reprezentáció. In: Horányi Özséb (szerk.): A sokarcú kép. Válogatott tanulmányok a képek logikájáról. Typotex, Budapest. 205-225.

Sekuler, R. és Blake, R. (2000): Észlelés. Osiris, Budapest.

Selfe, L. (1983): Normal and anomalous representational drawing ability in children. Academic Press, London - New York.

Souza, B. C. (1998): Creativity and problem solving: elements for a model of creativity. Cog Prints, 2013. 03. 04-i megtekintés, http://cogprints.org/1426/00/ creatmodel.htm

Steers, J. (2009): Creativity: Delusions, Realities, Opportunities and Challenges. International Journal of Art \& Design Education, 28. 2. sz. 126-138. DOI: 10.1111/j.1476-8070.2009.01600.x 
Steiner, R. (1992): Szabadságra nevelés. Török Sándor Waldorf Pedagógiai Alapítvány, Budapest.

Sully, J. (1896): Studies of Childhood. Appleton and Company. 2013. 11. 21-i megtekintés, https://archive. org/details/studieschildhoo00sullgoog DOI: $10.1037 / 11376-000$

Szalontai György (1994): Vizuális nevelés. Tárogató Kiadó, Budapest.

Székécsné Dr. Vida Mária (1982): A rajz tanitása. Tankönyvkiadó, Budapest.

Töreky Ferenc (2002): Vizuális kommunikáció. Nemzeti Tankönyvkiadó, Budapest.

Trencsényi László (1999): Az alternatív pedagógiák nyomában. Iskolakultúra, 9. 5. sz. 92-97.
Trencsényi László (2005): A tartalmi szabályozás hosszú története. Egy szemtanú magamentsége. In: Loránd Ferenc (szerk.): A tantervi szabályozásról és a bolognai folyamatról 2003-2004. Oktatási Minisztérium, Országos Köznevelési Tanács, Budapest. 37-44.

Vass Zoltán (2006): A rajzvizsgálat pszichodiagnosztikai alapjai. Flaccus Kiadó, Budapest.

Zombori Béla (1995): A vizuális nevelés új dimenziói. In: Kárpáti Andrea (szerk.): Bevezetés a vizuális kommunikáció tanitásához. Nemzeti Tankönyvkiadó, Budapest. 125-139. 